\title{
"The Impact of the Implication of Balanced Scorecard Model (BSC) in Performance of the Post Company"
}

\begin{tabular}{|c|c|}
\hline AUTHORS & $\begin{array}{l}\text { Soleyman Iranzadeh } \\
\text { Sadegheh Hosseinzadeh Nojehdeh } \\
\text { Nahideh Najafi Emami }\end{array}$ \\
\hline ARTICLE INFO & $\begin{array}{l}\text { Soleyman Iranzadeh, Sadegheh Hosseinzadeh Nojehdeh and Nahideh Najafi } \\
\text { Emami (2017). The Impact of the Implication of Balanced Scorecard Model (BSC) } \\
\text { in Performance of the Post Company. Problems and Perspectives in } \\
\text { Management, 15(4), 188-196. doi:10.21511/ppm.15(4-1).2017.03 }\end{array}$ \\
\hline DOI & http://dx.doi.org/10.21511/ppm.15(4-1).2017.03 \\
\hline RELEASED ON & Monday, 25 December 2017 \\
\hline RECEIVED ON & Monday, 18 September 2017 \\
\hline ACCEPTED ON & Tuesday, 05 December 2017 \\
\hline LICENSE & $\begin{array}{l}(\mathrm{cc}) \text { EY-NG } \\
\text { This work is licensed under a Creative Commons Attribution-NonCommercial } 4.0 \\
\text { International License }\end{array}$ \\
\hline JOURNAL & "Problems and Perspectives in Management" \\
\hline ISSN PRINT & $1727-7051$ \\
\hline ISSN ONLINE & $1810-5467$ \\
\hline PUBLISHER & LLC "Consulting Publishing Company "Business Perspectives" \\
\hline FOUNDER & LLC "Consulting Publishing Company "Business Perspectives" \\
\hline
\end{tabular}

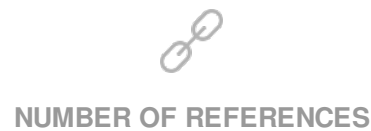

22

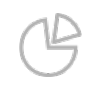

NUMBER OF FIGURES

0

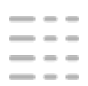

NUMBER OF TABLES

14

(c) The author(s) 2023. This publication is an open access article. 


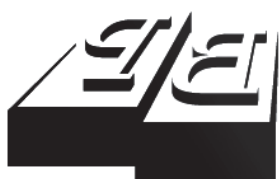

BUSINESS PERSPECTIVES

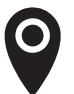

LLC "CPC "Business Perspectives" Hryhorii Skovoroda lane, 10, Sumy, 40022, Ukraine

www.businessperspectives.org

Received on: $18^{\text {th }}$ of September, 2017 Accepted on: $5^{\text {th }}$ of December, 2017

(C) Soleyman Iranzadeh, Sadegheh Hosseinzadeh Nojehdeh, Nahideh Najafi Emami, 2017

Soleyman Iranzadeh, corresponding author, Department of Management, Tabriz Branch, Islamic Azad University, Tabriz, Iran.

Sadegheh Hosseinzadeh Nojehdeh, Department of Management, Tabriz Branch, Islamic Azad University, Tabriz, Iran.

Nahideh Najafi Emami, Department of Management, Tabriz Branch, Islamic Azad University, Tabriz, Iran.

\section{(ㄷ)(1) $(8)$}

This is an Open Access article, distributed under the terms of the Creative Commons Attribution-NonCommercial 4.0 International license, which permits re-use, distribution, and reproduction, provided the materials aren't used for commercial purposes and the original work is properly cited.
Soleyman Iranzadeh (Iran), Sadegheh Hosseinzadeh Nojehdeh (Iran),

Nahideh Najafi Emami (Iran)

THE IMPACT OF THE

IMPLICATION OF BALANCED

SCORECARD MODEL (BSC)

IN PERFORMANCE

OF THE POST COMPANY

\begin{abstract}
Balanced scorecard model is a method to evaluate and control programs with adequate consistency. According to it, a certain organization is evaluated and controlled in terms of financial aspect, together with growth and learning, internal business processes and customer aspects. This research is practical in purpose and a descriptive inferential method has been used to collect data in addition to utilizing five-scale Likert questionnaire. In order to increase the accuracy of the study, all 320 employees of post company have been under evaluation. A one-sample t-test has been used to analyze the questions of the study. Furthermore, Friedman test has been used to investigate the differences among groups. The results of testing the hypotheses indicate the effect of growth and learning of the employees of post company, as well as internal business processes, customer and financial aspects on the performance of the post company. Moreover, Friedman test probing the differences among groups shows that internal business processes and customer variables have the most significant impact upon the performance of the post company, while growth and learning and financial aspects have the least significant effect on the performance of the post company.
\end{abstract}

\section{Keywords}

\section{JEL Classification}

performance evaluation, perspective, strategy, balanced scorecard, evaluation, post company

D04

\section{INTRODUCTION}

The increase in competition and the necessity to respond to stakeholders requires designing new patterns for evaluating organizational performance. The change in competition environment has proven the traditional criteria of performance evaluation to be inadequate in responding to the current needs of companies and governmental or non-governmental organizations. On the other hand, organizations are going through a transition from management based on mental approaches to a management based on reliable evidence. These organizations are collecting genuine numbers and utilize these numbers to determine, control and reach the desired level of performance. Performance evaluation system is in transition between mental management and management based on evidence (Davis \& Fisher, 2003).

Performance evaluation is a process during which managers gain some information about the performance of technical activities performed within an organization. Subsequently, they compare these performances to predetermined indices in budgeting, programs and objectives. Performance is evaluated in different levels of a company, in senior management, middle manufacturing unit supervisors in operational 
unit and employees of the sales department. In terms of the level, it is evaluated by the managers of manufacturing unit and these people are also management, operational level of manufacturing the perspective of operations, the performance of evaluated by the middle managers. By means of the same method, each of employees of the sales department will be evaluated by the sales department managers (Harbour, 1997).

\section{LITERATURE REVIEW}

\subsection{Performance evaluation}

Quantifying the acquired results in a certain standard and within a determined time range and then comparing it with expended resources is one of the main objectives of performance evaluation. This issue is related to the maximum use of people's capabilities and helping them achieve their individual potential, in other words, performance evaluation is a perspective to reach a mutual understanding of a company's objectives. This kind of management is linked with assisting individuals and teams to achieve their inner potential and determining their role in a company's goal achievement process (Hepworth, 1998).

Balanced scorecard method is considered by many to be one of the most comprehensive methods that has been used a lot in this era and many renowned companies have implemented it and benefited from its achievements (Kaplan \& Norton, 1992). This organization evaluation tool controls and monitors the performance of each and every component of the organization instantly, based on predetermined strategies and then compares them to organizational programs and objectives. This system measures and evaluates the success and progress rate of the organization in reaching its goals and eventually delivers accurate and precise reports to all levels of management within a company by the use of diagrams and graphs.

Applying BSC within an organization has the following applications (Kaplan \& Robin, 1998):

- It is a practical tool to clarify the organizational perspective and strategy. Firstly, when perspectives and strategies are interpreted in terms of learning and growth framework, some gaps and differences occur in mental models of senior managers. Next, this tool helps to close the gap between the different views of managers and create a strategic consensus.
- Facilitating the transmission of organizational perspective and strategy to different levels of an organization. BSC is an efficient tool to transmit organizational perspective and strategy, proposed by the senior management, to all personnel and people within an organization and announces the key criteria and objectives that is supposed to be pursued by the organization.

Simplifying and systemizing objective creation and programming. BSC helps senior managers to determine quantitative goals for the four aspects of financial, customers and so on within 3 to 5 years.

- Providing strategic feedbacks and elevating learning level. BSC enables managers to control how a certain strategy is implemented and make fundamental changes in strategies or implementation methods whenever necessary.

- Providing an atmosphere to control the progress of implementation of strategic objectives without the need for an evaluation system. The organization defines strategies. However, it may be forgotten at the time of crisis. BSC causes the organization to know how good the strategy has been implemented. Besides, the organization is always provided with a strategy.

- Accountability: BSC connects people's performance to the strategy causing each person to fee! Bound to achieve the desired results (Atkinson, 2006).

A new study indicates that approximately 75 percent of an organization's value is due to its intangible assets (Lauaand Mahfud, 2005). These assets differ from our traditional approach of them. They may not have a direct impact on financial outcomes. They reveal potential values and require a bilateral relationship. This transition from value creation 
by means of physical assets to value creation via intangible assets has had a major impact on performance evaluation systems. Balanced scorecard method emphasizes connections and cause and effect relationships to define organizational strategy. Hence, it provides an ideal tool to receive and convert the value of intangible assets (Heinz, 2001).

Although BSC method is originally associated with profit organizations, it has been utilized, successfully, by many governmental and nonprofit organizations (Niven, 2002).

\subsection{Balanced scorecard}

\subsubsection{The definitions of balanced scorecard}

- Balanced scorecard is a tool that interprets defined main strategies and objectives of the strategic plan to a comprehensive set of operational goals and programs so that it creates a framework for strategic monitoring and evaluation (Greet \& Edwin, 2004).

- Balanced scorecard is a system to evaluate performance that the main part consists of strategies, in this system, financial performance evaluation, customer, internal business processes and learning and growth criterion has been used.

- BSC is a method that assists organizations to transmit their strategies in the form of a set of operational goals to various parts of organizations. Thus it transforms performance behavior of the whole organization (Niven, 2002).

- BSC is a method that converts the organization strategy to measurable performance criterions so that a system to evaluate strategy is created (Sime, 2001).

\subsubsection{The aspects of balanced scorecard}

\section{Customer aspect}

In order to choose goals and measurements from the customer aspect, organizations must answer to fundamental questions. Firstly, who are our target customers? And secondly, what are our proposed values for them? Most organizations believe they know their customers and they are also well aware of what products and services to offer them. But they actually offer everything to all their customers (Wongrassam \& Simmoms, 2003).

- Operational advantage: organizations that choose operational advantage focus on low cost, improving product quality (applicability) and the ease of using their products and services.

- Product leadership: organizations that choose product leadership strategy, put emphasis on constant innovation and presenting the best product and service within the market.

- Intimacy with customers: in this strategy, the main objective of the organization is to satisfy the needs and desires of their customers and present solutions for their problems in addition to maintaining a long-term win-win relationship.

- Apart from the selection of each of the above strategies, the measurements that are widely used for this purpose in these companies are as follows: customer satisfaction, customer loyalty, market share and attracting and keeping customers (Ghahraman, 2011).

\section{Internal processes aspect}

In internal processes aspect, organizations must determine certain processes that excelling in them will enable them to continue their creation of value for their customers and eventually shareholders. The authentication of each of the objectives determined in customer aspect requires performing one or several operational processes effectively and efficiently (Clarke, 2001). These processes must be determined in internal processes aspect and appropriate measurement should be developed to control their progress. It is likely to need a completely new set of internal operations to meet the expectations of customers and shareholders. Developing new products and services, manufacturing, after sales services and reengineering are some of these processes. 


\section{Growth and learning aspect}

How can the ambitious objectives set by internal processes and customer aspect and eventually shareholders be achieved? The answer to this question is hidden among the objectives and measurements of the customers and internal operations aspect. In fact, these objectives and measurements are the enablers of determined objectives in the other three aspects. They are the infrastructure and foundation of implementing balanced scorecard system. When you have determined the objectives and measurements for the customer and internal operations aspect, immediately, you realize a gap between the required skills and capabilities of the employees and the current level of these skills and capabilities. Moreover, the gap between the required information technology and the present IT level of the organization is recognized within a short period of time (Millis \& Merken, 2004).

\section{Financial aspect}

Financial measurement are one of the most important components of BSC system. Specifically, in profit organizations, these measurements tell us the type of results and achievements gained by the successful implementation of the objectives determined in the other three aspects. We can do our best to improve customer satisfaction, product quality and the reduction of products and services delivery time. However, if these steps do not result in tangible outcomes in our financial reports, they will not be of significant value. The indices of the classic function usually show themselves in financial aspect (Blocher, Chen, \& Lin, 1999). Examples of these indices and measurements are profitability which is assessed according to the utilized capital and recently added value index has been considered instead of it or together with it in addition to profitability, salary growth and productivity increase or utilizing assets are some of the most well-known measurements of this aspect (Davis \& Albright, 2004).

\subsection{Five basics of a strategy-based organization}

- Translate strategy into operational terms. BSC provides an instruction which combines the components and elements within an organi- zation for long term value creation. This method provides a frame work to articulate and transmit strategy in a constant and planned manner.

Coordinate the organization in the direction of strategy, in order for the company to have a more optimum performance compared to the sum of the performances of each department, on the one hand, individual strategies must be combined and merged and, on the other hand, since traditional companies are usually designed based on functional expertise, each department acts as an obstruction to the implementation of strategy and organizations must deal with the problem of coordination and communication among units. Strategy-based organizations overcome this barrier and spread notions with coordinated messages and priorities throughout the organizational units (Creelman, 2008).

- Convert the strategy with the daily tasks of employees. Managers of prospering organizations cannot implement new strategies single handedly, but they also need the active participation of all the staff. A strategy-based company requires all its employees to comprehend the strategy and perform their daily duties in a way that would help the success of the strategy. This is not a top-down order but it is a top-down cooperation and relationship. Instead of transmitting objectives via directorial hierarchy, the whole set of strategy is transmitted from top to bottom. Therefore, all the staff and organizational units can define their objectives in the light of wider fundamentals (Anderson \& Shulver, 2000).

Convert strategy to a constant process: researches show that 85 percent of management teams allot less than an hour of their time each month to discuss about strategy so no wonder that a strategy implementation fails. Successful organizations use a double loop process to manage strategies. A process that links tactics management and strategy management to create a unified process. According to this process, (1) strategy is linked with budgeting process; (2) special management sessions (monthly, fortnightly...) are held on a 
regular basis known as simple management sessions in order to review the strategy so that a wide range of managers can talk about the strategy; (3) a process is created to learn and compatibility of the strategy. In fact, immediately, after the implementation of BSC, feedback systems present progress reports and enable the organizations to examine the strategic hypotheses (Smite, 2006).

- Move the transformation by means of senior management leadership: for a strategy-based organization, something more than tools and processes is needed. Prior experience shows that the most important condition of success is the active cooperation of senior managers. Since BSC is not an evaluation project but a transformational process, if those at the top of the organization are passive leaders for this process, transformation will never occur. Strategy will not be implemented and the opportunity for a successful performance is missed (Lomotte, 2000).

\section{RESEARCH METHODOLOGY}

The methodology of the study is descriptive inferential. Since, in this study, we try to describe the impact of implementing balanced scorecard method on the performance of post company, and our analyze unit is individual, we have utilized the inferential method.

\subsection{Sampling techniques}

In this study, library research method has been used so that the researcher can go to different data resources such as documents, journals and books, previous studies, statistical data from statistical centers and so on. In other words, this set of data has not been collected by the researcher but it already exists and the researcher utilizes it. Furthermore, the researcher has collected part of his/her data via the distribution of questionnaires in the study population. The questionnaire of this study is researcher made and it is a closed format questionnaire and a five point Likert scale has been used in it.

Reliability is the overall consistency of a measure. A measure is said to have a high reliability if it produces similar results under consistent conditions. The more similar the results are, the higher reliability a questionnaire has. In order to determine the reliability of a questionnaire, Cronbach's alpha coefficient was used. Thus, after the distribution of the questionnaire among 50 people of the study population, its alpha was calculated and it has a high reliability according to Table 1 . In order to determine the validity of the questionnaire, content validity method was used. Therefore, the questionnaire has been modified according to the opinions of related professors.

Table 1. Questionnaire aspects alpha

\begin{tabular}{l|c}
\hline \multicolumn{1}{c|}{ Aspects } & Cronbach's alpha, \% \\
\hline Growth and learning & 84 \\
\hline Internal processes & 85 \\
\hline Customer & 84 \\
\hline Financial & 85 \\
\hline Overall questionnaire & 93 \\
\hline
\end{tabular}

The study population of the current research is: all the staff employees of post company which are a total of 220 people. According to Morgan table, 140 people were selected as the sample size and in order to increase the generalization capability of survey findings, sample size was increased to 185 people. Sampling method, used in this survey, has been the proportional stratified sampling. In Table 2 , minimum, maximum, average and standard deviation of studied variables scores are indicated.

\subsection{Data analysis methods}

Furthermore, after the primary revision of the collected questionnaires, encoding the questions and questionnaire, data were imported to the comput-

Table 2. Minimum, maximum, average and standard deviation of studied variables scores

\begin{tabular}{|c|c|c|c|c|c|}
\hline Variables & Number of people & Minimum & Maximum & Average & Standard deviation \\
\hline Growth and learning & 185 & 2.00 & 5.00 & 3.7297 & .78188 \\
\hline Internal operations & 174 & 3.00 & 5.00 & 4.4598 & .57510 \\
\hline Customer & 185 & 2.00 & 5.00 & 4.2541 & .63870 \\
\hline Financial & 185 & 1.00 & - & 3.7027 & .67827 \\
\hline
\end{tabular}


er and analyzed via SPSS. According to the type of research and variables, both descriptive and inferential (one-sample $t$-test) statistical indices were utilized and then the acquired data have been described and categorized.

\section{HYPOTHESIS TESTING AND DISCUSSIONS}

Test of the basic hypotheses of the study:

Zero hypothesis: the implementation of balanced scorecard has had no impact on the performance of post company.

Opposing hypothesis: the implementation of balanced scorecard has had an impact on the performance of post company.

HO: $\quad \mu \leq 3$

H1: $\quad \mu>3$

The results of hypotheses test are illustrated in Tables 3 and 4.

Table 3. Descriptive statistics

\begin{tabular}{|c|c|c|c|c|}
\hline Variables & $\begin{array}{c}\text { Number } \\
\text { of people }\end{array}$ & Average & $\begin{array}{l}\text { Standard } \\
\text { deviation }\end{array}$ & $\begin{array}{c}\text { Average } \\
\text { standard } \\
\text { error }\end{array}$ \\
\hline $\begin{array}{l}\text { Management } \\
\text { implementation }\end{array}$ & 174 & 4.0302 & .54311 & .04117 \\
\hline $\begin{array}{l}\text { Performance } \\
\text { evaluation }\end{array}$ & & & & \\
\hline
\end{tabular}

Table 4. $t$-test

\begin{tabular}{|c|c|c|c|c|c|c|}
\hline \multirow{3}{*}{ Variable } & \multicolumn{6}{|c|}{ Test amount $=3$} \\
\hline & \multirow{2}{*}{$\mathbf{T}$} & \multirow{2}{*}{ 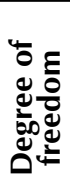 } & \multirow{2}{*}{ 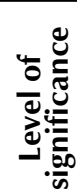 } & \multirow{2}{*}{ 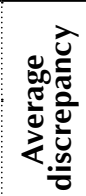 } & \multicolumn{2}{|c|}{$\begin{array}{l}\text { Certainty } \\
\text { distance } 95 \% \\
\text { of discrepanc }\end{array}$} \\
\hline & & & & & $\begin{array}{l}\text { Lower } \\
\text { bound }\end{array}$ & $\begin{array}{l}\text { Upper } \\
\text { bound }\end{array}$ \\
\hline $\begin{array}{l}\text { The } \\
\text { implementation } \\
\text { of performance } \\
\text { management }\end{array}$ & 25.021 & 173 & .000 & 1.0302 & .9489 & 1.1114 \\
\hline
\end{tabular}

In order to determine if the implementation of balanced scorecard (BSC) has had an impact on the performance of post company, a $t$-test with one sample was performed. Sample average was 4.03 and the standard deviation was 0.54 which has a significant divergence with the expected amount which is 3
$(P>0.001, t(d F=173)=25.02)$. Thus, it can be claimed that zero hypothesis is rejected and the opposing hypothesis, which indicated that the implementation of balanced scorecard (BSC) has had an impact on the performance of post company, is verified.

\section{Test of subordinate hypothesis 1}

Zero hypothesis: growth and learning of employees has not had an impact on the performance of post company.

Opposing hypothesis: growth and learning of employees has had an impact on the performance of post company.

\section{HO: $\quad \mu \leq 3$ \\ H1: $\quad \mu>3$}

The results of hypotheses test are illustrated in Tables 5 and 6.

Table 5. Descriptive statistics

\begin{tabular}{l|c|c|c|c}
\hline Variable & $\begin{array}{c}\text { Number } \\
\text { of people }\end{array}$ & Average & $\begin{array}{c}\text { Standard } \\
\text { deviation }\end{array}$ & $\begin{array}{c}\text { Average } \\
\text { standard } \\
\text { error }\end{array}$ \\
\hline $\begin{array}{l}\text { Growth and } \\
\text { learning }\end{array}$ & 185 & 3.7297 & .78188 & .5749 \\
\hline
\end{tabular}

Table 6. $t$-test

\begin{tabular}{|c|c|c|c|c|c|c|}
\hline \multirow{3}{*}{ Variable } & \multicolumn{6}{|c|}{ Test amount $=3$} \\
\hline & \multirow[t]{2}{*}{$\mathbf{T}$} & \multirow{2}{*}{ 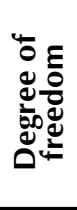 } & \multirow{2}{*}{ 峁导 } & \multirow{2}{*}{ 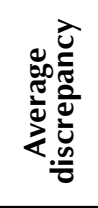 } & \multicolumn{2}{|c|}{$\begin{array}{c}\text { Certainty, } \\
\text { distance } \\
95 \% \text { of } \\
\text { discrepancy }\end{array}$} \\
\hline & & & & & $\begin{array}{l}\text { Lower } \\
\text { bound }\end{array}$ & $\begin{array}{l}\text { Upper } \\
\text { bound }\end{array}$ \\
\hline $\begin{array}{l}\text { Growth } \\
\text { and } \\
\text { learning }\end{array}$ & 12.694 & 184 & .000 & .7297 & .6163 & .8431 \\
\hline
\end{tabular}

In order to determine if growth and learning of employees has had an impact on the performance of post company, a $t$-test with one sample was performed. Sample average was 3.72 and standard deviation was 0.78 , which has a significant divergence with the expected amount which is $3\left(t(d F=184)=\frac{12}{69}, P<0.001\right)$. Hence, it can be claimed that zero hypothesis is rejected and the opposing hypothesis, which is that growth and learning of employees has had an impact on the performance of post company is verified. 


\section{Test of subordinate hypothesis 2}

Zero hypothesis: internal processes have not had an impact on the performance of post company.

Opposing hypothesis: internal processes have had an impact on the performance of post company.

HO: $\quad \mu \leq 3$

H1: $\quad \mu>3$

The results of hypotheses test are illustrated in Tables 7 and 8.

Table 7. Descriptive statistics

\begin{tabular}{l|c|c|c|c}
\hline Variable & $\begin{array}{c}\text { Number } \\
\text { of people }\end{array}$ & Average & $\begin{array}{c}\text { Standard } \\
\text { deviation }\end{array}$ & $\begin{array}{c}\text { Average } \\
\text { standard } \\
\text { error }\end{array}$ \\
\hline $\begin{array}{l}\text { Internal } \\
\text { processes }\end{array}$ & 174 & 4.4598 & .57510 & .04360 \\
\hline
\end{tabular}

Table 8. $t$-test

\begin{tabular}{|c|c|c|c|c|c|c|}
\hline \multirow{3}{*}{ Variable } & \multicolumn{6}{|c|}{ Test amount $=3$} \\
\hline & \multirow{2}{*}{$\mathbf{T}$} & \multirow{2}{*}{ 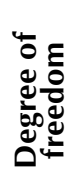 } & \multirow{2}{*}{ 苞 } & \multirow{2}{*}{ 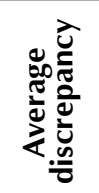 } & \multicolumn{2}{|c|}{$\begin{array}{c}\text { Certainty } \\
\text { distance } 95 \% \\
\text { of discrepancy } \\
\end{array}$} \\
\hline & & & & & $\begin{array}{l}\text { Lower } \\
\text { bound }\end{array}$ & $\begin{array}{l}\text { Upper } \\
\text { bound }\end{array}$ \\
\hline $\begin{array}{l}\text { Internal } \\
\text { processes }\end{array}$ & 33.482 & 173 & .000 & 1.4598 & 1.3737 & 1.5458 \\
\hline
\end{tabular}

In order to determine if internal processes have had an impact on the performance of post company, a $t$-test with one sample was performed. Sample average was 4.45 and standard deviation was 0.57 which has a significant divergence with the expected amount which is 3 $(t(d F=173)=33.48, P<0.001)$.

Hence, it can be claimed that zero hypothesis is rejected and the opposing hypothesis, which is that internal processes have had an impact on the performance of post company is verified.

\section{Test of subordinate hypothesis 3}

Zero hypothesis: customer care has not had an impact on the performance of post company. Opposing hypothesis: customer care has not had an impact on the performance of post company.

$$
\begin{array}{ll}
H 0: & \mu \leq 3 \\
H 1: & \mu>3
\end{array}
$$

The results of hypotheses test are illustrated in Tables 9 and 10.

Table 9. Descriptive statistics

\begin{tabular}{l|c|c|c|c}
\hline Variable & $\begin{array}{c}\text { Number } \\
\text { of people }\end{array}$ & Average & $\begin{array}{c}\text { Standard } \\
\text { deviation }\end{array}$ & $\begin{array}{c}\text { Average } \\
\text { standard } \\
\text { error }\end{array}$ \\
\hline $\begin{array}{l}\text { Customer } \\
\text { care }\end{array}$ & 185 & 4.2541 & .63870 & .04696 \\
\hline
\end{tabular}

\begin{tabular}{|c|c|c|c|c|c|c|}
\hline \multirow{3}{*}{ Variable } & \multicolumn{6}{|c|}{ Test amount $=3$} \\
\hline & \multirow{2}{*}{$\mathbf{T}$} & \multirow{2}{*}{ 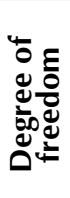 } & \multirow{2}{*}{ 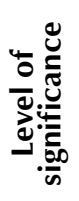 } & \multirow{2}{*}{ 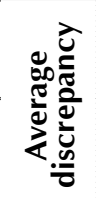 } & \multicolumn{2}{|c|}{$\begin{array}{c}\text { Certainty } \\
\text { distance } 95 \% \\
\text { of discrepancy }\end{array}$} \\
\hline & & & & & $\begin{array}{l}\text { Lower } \\
\text { bound }\end{array}$ & $\begin{array}{l}\text { Upper } \\
\text { bound }\end{array}$ \\
\hline $\begin{array}{l}\text { Customer } \\
\text { care }\end{array}$ & 26.706 & 184 & .000 & 1.2541 & 1.1614 & 1.3467 \\
\hline
\end{tabular}

Table 10. $t$-test

In order to determine if customer care has had an impact on the performance of post company, a $t$-test with one sample was performed. Sample average was 4.45 and standard deviation was 0.57 which has a significant divergence with the expected amount which is 3 $(t(d F=184)=26.70, P<0.001)$. Hence, it can be claimed that zero hypothesis is rejected and the opposing hypothesis, which is that customer care has had an impact on the performance of post company, is verified.

\section{Test of subordinate hypothesis 4}

Zero hypothesis: financial processes have not had an impact on the performance of post company.

Opposing hypothesis: financial processes have had an impact on the performance of post company.

\section{HO: $\quad \mu \leq 3$}

H1: $\quad \mu>3$

The results of hypotheses test are illustrated in Tables 11 and 12.

Table 11. Descriptive statistics

\begin{tabular}{l|c:c|c|c}
\hline Variable & $\begin{array}{c}\text { Number } \\
\text { of } \\
\text { people }\end{array}$ & Average & $\begin{array}{c}\text { Standard } \\
\text { deviation }\end{array}$ & $\begin{array}{c}\text { Average } \\
\text { standard } \\
\text { error }\end{array}$ \\
\hline $\begin{array}{l}\text { Financial } \\
\text { processes }\end{array}$ & 185 & 3.7027 & .67827 & .04987 \\
\hline
\end{tabular}


Table 12. $t$-test

\begin{tabular}{|c|c|c|c|c|c|c|}
\hline \multirow{3}{*}{ Variable } & \multicolumn{6}{|c|}{ Test amount $=3$} \\
\hline & \multirow{2}{*}{$\mathbf{T}$} & \multirow{2}{*}{ 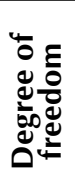 } & \multirow{2}{*}{ 苋 } & \multirow{2}{*}{ 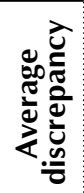 } & \multicolumn{2}{|c|}{$\begin{array}{c}\text { Certainty } \\
\text { distance } 95 \% \\
\text { of discrepancy } \\
\end{array}$} \\
\hline & & & & & $\begin{array}{l}\text { Lower } \\
\text { bound }\end{array}$ & $\begin{array}{l}\text { Upper } \\
\text { bound }\end{array}$ \\
\hline $\begin{array}{l}\text { Financial } \\
\text { processes }\end{array}$ & 14.091 & 184 & .000 & .7027 & .6043 & .8011 \\
\hline
\end{tabular}

In order to determine if financial processes have had an impact on the performance of post company, a $t$ test with one sample was performed. Sample average was 4.45 and standard deviation was 0.57 which has a significant divergence with the expected amount which is $3 \quad(t(d F=184)=14.09, P<0.001)$. Hence, it can be claimed that zero hypothesis is rejected and the opposing hypothesis, which is that financial processes have had an impact on the performance of post company, is verified.

Friedman test has been performed in order to determine the differences among groups. In Table 13, rank averages are indicated. In Table 14, Chi- square test with 2 or 3 degrees of freedom and the significance level of 0.000 is significant. According to presented output, the final results show that internal operations and customer care variables have the most impact on the performance of post company, while growth and learning and financial aspects have the least impact on the performance of post company.

Table 13. Friedman test

\begin{tabular}{l|c}
\hline \multicolumn{1}{c|}{ Variables } & Averages \\
\hline Growth and learning & 2.00 \\
\hline Internal processes & 3.23 \\
Customer care & 2.86 \\
\hdashline Financial aspect & 1.91 \\
\hline
\end{tabular}

Table 14. Chi-square test

\begin{tabular}{l|c}
\hline Number of people & 174 \\
\hline Overall statistic & 213.633 \\
\hdashline Degree of freedom & 3 \\
\hline Level of significance & .000 \\
\hline
\end{tabular}

\section{CONCLUSION AND FUTURE SUGGESTIONS}

After analyzing statistical data and according to the results of research hypothesis tests which gives us the main results of the research that verifies all the Hypothesis of the study, it can be claimed that the implementation of balanced scorecard has had an impact on the performance of post company. According to this, paying attention to growth and learning processes of the employees, customer care, financial tasks, and also internal processes as the symbols of performance evaluation management (BSC method), have effectively played a key role to improve the overall performance of the company. In this respect, internal processes and customer care variables that have the most impact on the performance of post company, must be approached with more attention, care and emphasis form a managerial perspective. Apart from these results, some of the previous studies also confirm these findings.

\section{Future suggestions}

1. Since growth and learning of the employees has an impact on the performance of post company, we propose to take action in the development of human capital to provide them with the access to skills, talents and instructions. Moreover, action must be acted in the field of information capital to let the employees have access to information systems and networks.

2. The findings of this study have illustrated that paying attention to internal processes has an impact on the performance of post company. So we propose to improve the internal operations of post company which are criterions such as utilizing capacity, on time delivery, time duration, quality (indices like the number of wastes ...), and inventory flow and so on.

3. We propose to investigate the level of satisfaction among the customers of the post company in addition to trying to determine the most important factors involved in customer satisfaction and 
maintenance (organization-customer average communication time), customer loyalty (the number of customer purchase and return) and making efforts to improve them. Furthermore, by means of land and good tempered employees, providing amenities and informing customers, we should give customers an opportunity to return to governmental companies.

4. Criteria such as profit, revenue growth, investment return must be observed incessantly and new technologies must be utilized in different working areas in order to improve financial tasks of the post companies

\section{REFERENCES}

1. Andersen, H. V., Lawrie, G., \& Shulver, M. (2000). The balanced Scorecard VS. The EFQM Business Excellence Model. 2GC Limited.

2. Atkinson, H. (2006). Strategy implementation: A role for the balanced Scorecard? Management Decision, 49(10), 1441-1460. Retrieved from http://www. emeraldinsight.com/doi/ abs/10.1108/00251740610715740

3. Blocher, E. J., Chen, K. H. \& Lin, T.IV. (1999). Cost Management: A Strategic Emphasis, Irwin/ McGraw-Hill.

4. Chong, L. M., \& Sholihin, M. (2005). Financial and nonfinancial performance measures: How do they affect job satisfaction? The British Accounting Review, 37(4), 389-413.

5. Clarke, S. (2001). Information systems and strategic management: An integrated approach.

6. Creelman, J., \& Makhijani, N. (2008). How Leading organizations successfully implement corporate strategy with the balanced scorecard. The OTI thought Leadership. Series, 1, 1-16.

7. Davis, D., \& Fisher, T. (2003). Attitudes of middle managers to quality - based organizational change. Managing service Quality, 12, 405-413.

8. Davis, S., \& Albright, T. (2004). An investigation of the effect of balanced score card implementation on financial performance. N. P. Retrieved from http://www.sciepub.com/reference/154636
9. Ghahraman, Mohammad Reza (2011). Twelve steps to define and implement balanced scorecard. Bazga publication, Tehran.

10. Greet, J. M., \& Edwin, J. N. (2004). Performance effects of using the balanced scorecard: A note on the Dutch experience. N.P.

11. Harbour, Jerry L. (1997). The Basics of Performance Measurement. Productivity Press.

12. Heinz, A. (2001). Applying the Balanced Scorecard concept: An Experience Report. Long Range Planning, 34. Retrieved from https://www.scribd.com/document/187851597/Applying-theBalanced-Scorecard-Concept-aCase-Study-of-ABB

13. Hepworth, P. (1998). Weighing it up - a literature review for the Balanced Scorecard. Journal of Management development, 17(8), 559-563.

14. Kaplan, R. S., \& Norton, D. P. (2004). Having Trouble with your strategy? Then Map It! Boston: Harvard Business Review. Retrieved from https://www.ncbi. nlm.nih.gov/pubmed/11143152

15. Kaplan, R. S., \& Norton, D. P. (1992). The balanced scorecard: Measures that drive performance. Harvard business review.

16. Kaplan, R. S., \& Robin, C. (1998). Cost and effect: Using integrated cost systems to drive profitability and performance. Boston: Harvard business school press.

17. Lomotte, G., \& Carter, G. (2000). Are the Balanced Scorecard and the EFQM Excellence Model Mutually Exclusive or do they work together to Bring added Value to a company? Working Paper, 2, 49-58. Retrieved from http://strategymanagement.com/wp-content/ uploads/2014/10/EFQM-andBalanced-Scorecard.pdf

18. Milis, K., \& Mercken, R. (2004). The use of the balanced scorecard for the evaluation of Information and Communication Technology projects. International Journal of Project Management 22, 87-97.

19. Niven, P. R. (2002). Balanced scorecard step-by-step. John Wiley \& Sons Inc. Retrieved from http:// www.vra.com/ vralibrary/ebooks/ Balanced_Scorecard_Step_by_ Step.pdf

20. Sime, K. L., Koh, H. C. (2001). Balanced Scorecard: A rising trend in strategic performance. Measuring Business Excellence, 5(2), 18-26.

21. Smith, R. (2006). Business Process Management and Balanced Scorecard: Focusing Processes on strategic Drivers. Kindle Edition.

22. Wongrassam, S., Gardiber, P. D., \& Simmons, J. E. L. (2003) Performance Measurement Tools: The Balanced Scorecard and the EFQM Excellence Model. Measuring Business Excellence, 7(1), 14-28. 